AGRICA: Journal of Sustainable Drayland Agriculture, 14 (1): 32-46 (2021)

ISSN-Online: 2715-4955; ISSN-Cetak: 2715-6613

DOI: https://doi.org/10.37478/agr.v14i1.1007

\title{
HUBUNGAN POPULASI CACING TANAH TERHADAP C-ORGANIK DAN N-TOTAL DI LAHAN BUDIDAYA HORTIKULTURA DAN MONOKLUTUR TANAMAN KOPI DI DESA NDUARIA
}

\author{
Muksin dan Agustinus J. P Anasaga \\ Program studi Agroteknologi, Fakultas Pertanian Universitas Flores \\ Jln. Sam Ratulanggi XX Paupire, Ende, Nusa Tenggara Timur \\ needyysagga@gmail.com
}

\begin{abstract}
Relationship Of Earthworm Population On C-Organic And N-Total In Horticultural Cultivation And Coffee Monocluture Land In Nduaria Village. This study aims to determine the relationship between Earthworm Population and C-organic and N-total in Horticulture and Coffee Monoculture cultivation in Nduaria Village, Kelimutu District. This research was conducted using an exploratory method that is carried out by direct observation from the observation location. How to calculate earthworms using the hand sorting method. The method commonly used for the determination of C-organic is the Walkley and Black method, while the method used for the determination of $\mathrm{N}$-total is the Kjehdahl method. This method is used because it is considered simple, fast, easy to do and requires little equipment. The results of this study indicate that in horticultural land there is no earthworm population found at all depths. Earthworm populations were found at all depths in the coffee plantation monoculture, the highest population was at a depth of $0-10 \mathrm{~cm}$ as many as $41 \mathrm{~m}^{2}$, Biomass was $9 \mathrm{~g}$ and Biomass vs Population $0.21 \mathrm{~m}^{2}$. In horticultural fields, the highest c-organic and n-total is at a depth of 0-10 $\mathrm{cm}$, the c-organic value is $3.03 \%$ (high criteria) and n-total is $0.47 \%$ (medium criteria). The close relationship between the earthworm population, biomass and biomass versus population was positively correlated with c-organic and n-total in horticultural land and coffee monoculture.
\end{abstract}

Key words: C-organic, Eartworm, N-total, Population

\section{PENDAHULUAN}

Tanah adalah salah satu sumber daya utama dalam bidang pertanian. Tanah yang ideal bagi usaha pertanian adalah tanah dengan sifat fisika, kimia dan biologi yang baik. Secara fisika, tanah berfungsi sebagai tempat tumbuh dan berkembangnya perakaran tanaman serta menyuplai kebutuhan air dan udara. Secara kimia, tanah berfungsi sebagai gudang dan penyuplai unsur hara. Sedangkan secara biologi, tanah berfungsi sebagai habitat organisme tanah yang aktif dalam penyediaan hara dan zat-zat aditif bagi pertumbuhan tanaman. Selain itu 
Muksin : Hubungan populasi cacing tanah terhadap C-organik dan N-total

tanah juga berfungsi sebagai salah satu bagian dari ekosistem (Irawati et al., 2019).

Tanah kaya akan berbagai jenis fauna tanah dengan berbagai ukuran dan bentuk kehidupan. Komponen biotik di dalam tanah memberikan sumbangan terhadap proses aliran energi dan ekosistem ditanah. Organisme tanah berperan dalam aliran energi dengan cara menggunakan energi matahari dan menamabah $\mathrm{CO}_{2}$, memasuki bahan organk ke dalam tanah, hara dalam, menghasilkan senyawa organik barau sebagai sumber energi dan nutrisi organisme lain dan lain sebagainya (Hani dan Suhaendah, 2019).

Fauna tanah merupakan salah satu komponen dalam ekosistem tanah, berperan dalam memperbaiki struktur tanah melalui penemuan berat jenis (bluk density), peningkatan ruang pori, areasi, dranase, kapasitas penyimpanan air, dekomposisi sisa organik, pencemaran partikel tanah dan penyebaran mikroba. Selain itu fauna tanah juga berperan dalam menentukan kesuburan tanah dan akan menjadi idikator tingkat kesehatan tanah di satu lahan pertanian (Batubara et al., 2013).

Desa Nduaria terletak di Kecamatan Kelimutu, Kabupaten Ende- Flores, Nusa Tenggara Timur. Berada pada ketinggian kurang lebih $1095 \mathrm{~m}$ di atas permukaan laut, berhawa sejuk dengan suhu rata-rata sekitar 25-27 ${ }^{\circ} \mathrm{C}$. Berdasarkan hasil wawancara dengan para pertani Desa Nduaria, hasil pertanian yang lebih dominan di Desa Nduaria adalah tanaman hortikultura dan komoditi perkebunan monokultur kopi. Teknik budidaya tanaman tersebut meliputi pengolahan lahan, penggunaan pupuk dan pestisida. Pengolahan lahan dilakukan secara tradisional dan modern. Dalam penggunaan pupuk, oleh para petani Desa Nduaria menggunakan pupuk organik dan anorganik. Sedangkan penggunaan pestisida ada yang menggunakan pestisida alami dan buatan.

Pengolahan lahan dan penggunaan pupuk dan pestisida akan mempengaruhi keberadaan mikroorganisme dan makrooganisme tanah. Cacing tanah merupakan salah satu makroorganisme tanah. Cacing tanah berfungsi menyebarkan kembali zat-zat organik dalam tanah dengan cara mengonsumsi memecahnya dan mengeluarkan kembali sehingga dapat menyuburkan tanah (Luthfiyah, 2014).

Tanah dengan kepadatan populasi cacing tanah yang tinggi akan menjadi subur karena cacing tanah mampu menghancurkan partikel-partikel mineral menjadi unit-unit yang lebih kecil dan membantu percampuran antara tanah lapisan atas dan bawah. Hal tersebut mengakibatkan distribusi dan siklus 
C-organik lebih lama berada di tanah. Cacing tanah menghasilkan kotoran (kascing) yang memiliki kandungan hara dan $\mathrm{C}$ yang tinggi dibandingkan tanah karena mengandung suatu campuran mineral tanah dan bahanbahan organik yang terdekomposisi. Kascing mengandung berbagai bahan yang dibutuhkan untuk pertumbuhan tanaman yaitu suatu hormon seperti giberelin, sitokinin dan auksin, serta mengandung unsur hara $(\mathrm{N}, \mathrm{P}, \mathrm{K}, \mathrm{Mg}$, dan $\mathrm{Ca})$ dan Azotobacter sp. yang merupakan bakteri penambat $\mathrm{N}$ non-simbiotik yang akan membantu memperkaya unsur $\mathrm{N}$ yang dibutuhkan olah tanaman (Fonte dan Six, 2010).

Penelitian Schwab at al. (2015) menunjukkan bahwa tanah dengan populasi cacing tanah yang tinggi memiliki bahan organik, total $\mathrm{N}$, kapasitas tukar kation (KTK), $\mathrm{Ca}$, $\mathrm{Mg}$, dan $\mathrm{K}$ yang dapat dipertukarkan, $\mathrm{N}$ dan $\mathrm{P}$ tersedia yang lebih tinggi. Hal ini disebabkan karena aktifitas cacing tanah sangat meningkatkan konsentrasi $\mathrm{N}$ anorganik (terutama $\mathrm{NH}_{4}$ ) dalam tanah. Kandungan $\mathrm{N}$ mineral, total karbon, total nitrogen, dan biomassa mikroba meningkat pada lahan yang diinokulasi cacing tanah (Muys dan Granval, 1997). Penelitian ini bertujuan untuk mengetahui populasi, biomassa, dan rasio biomasa dan populasi pada lahan budidaya tanaman hortikultura dan monokultur tanaman kopi di desa Nduaria Kecamatan Kelimutu dan untuk mengetahui hubungan Populasi cacing tanah terhadap C-organik dan N-total. Penelitian ini mengkaji peran cacing tanah dalam menjaga kesuburan tanah dan keseimbangan ekosistem tanah yang berhubungan dengan pertanian berkelanjutan.

\section{BAHAN DAN METODE}

Penelitian ini dilaksanakan di kebun petani Desa Nduaria di Dusun 1 dan Dusun 3, Kecamatan Kelimutu, Kabupaten Ende Flores, Nusa Tenggara Timur. Waktu pelaksanaan penelitian selama kurang lebih satu bulan yaitu pada bulan September tahun 2019. Bahan yang digunakan dalam penelitian ini adalah sampel tanah yang di ambil di lahan budidaya hortikultura, kantong plastik, karet gelang. Alat yang digunakan cangkul, parang, clinometer, kamera dan alat tulis.

Penelitian ini merupakan jenis penelitaian deskriptif kualitatif. Pengambilan data menggunakan metode eksploratif yakni di lakukan dengan cara pengamatan secara langsung dari lokasi pengamatan. Cara perhitungan cacing tanah dengan menggunakan metode pemilihan dengan tangan (hand sorting) (Sagita et al., 2014). 
Muksin : Hubungan populasi cacing tanah terhadap C-organik dan N-total

\section{Parameter Pengamatan}

\section{Populasi Cacing Tanah}

Parameter yang diamati yaitu: Populasi cacing tanah (ekor), dengan menggunakan metode hand sorting. (Sagita et al., 2014)

Rumus menghitung populasi cacing tanah.

$$
\mathrm{K}=\frac{\text { Jumlah cacing tanah }}{\text { Jumlah unit sampel }}
$$

Ket. : $\mathrm{K}=$ Kepadatan populasi cacing tanah (individu/m2)

\section{Biomassa Cacing Tanah}

Pengamatan biomaasa cacing tanah dilakukan ditiap petak percobaan dalam beberapa periode waktu pengamatan yakni pengamatan secara kontinyu selama masa penelitian. Cacing tanah yang di temukan di timbang biomasanya di masing - masing ulangan dan ke dalaman. (Sagita et al., 2014) Rumus perhitungan biomassa cacing tanah:

$$
A=\frac{\text { Berat cacing tanah }}{\text { Jumlah cacing tanah }}
$$

Ket. : A = unit sampel.

\section{Perbandingan Biomassa dan Populasi \\ Cacing Tanah}

Perbandingan biomasa cacing tanah dan populasi cacing tanah di lakukan pada periode pengamatan biomasa dengan jumlah cacing tanah yang berada pada tiap sampel penelitian.

Rumus perbandingan Biomassa dan jumlah cacing tanah

$$
\mathrm{R}=\frac{\text { Biomassa cacing tanah }}{\text { Jumlah cacing tanah }}
$$

$$
\text { Ket.: } \mathrm{R}=\text { Rasio }
$$

\section{C-Organik}

Metode yang biasa dipakai untuk penentuan C-Organik adalah metode Walkley and Black. Hitung kadar C-Organik, dengan menggunakan rumus :

$$
\begin{array}{ll}
\text { \%C-Organik }=\frac{(\mathrm{me} \mathrm{K} 2 \mathrm{Cr} 207-\mathrm{meFeS04}) \times 0,003 \times 100 \times f}{\mathrm{BKM}} \\
\text { me } \quad=\mathrm{N} \times \mathrm{v} \\
\mathrm{v} \quad=\text { Volume } \\
\mathrm{N} \quad=\text { Normalitas } \\
\mathrm{BKM} \quad=\text { Bobot Kering Oven } 150^{\circ} \text { Contoh. }
\end{array}
$$

\section{N-Total}

Dalam penetapan $\mathrm{N}$-total dengan metode Kjehdahl, nitrogen diubah dalam bentuk amonium, pada destruksi dengan asam sulfat pekat yang mengandung katalis dan zat-zat kimia lainnya yang dapat meningkatkan suhu pada waktu-waktu destruksi. Kemudian amonium ditetapkan dari jumlah amoniak yang dibebaskan pada penyulingan destrat. Bentuk-bentuk nitrogen anorganik yang dapat ditemukan dalam tanah adalah bentuk amonium, nitrat dan nitrit.

\section{Analisis Data}

Pada penelitian ini untuk mengetahui sebaran data populasi cacing tanah, biomassa cacing tanah yang diperoleh dari hasil pengamatan uji korelasi antara populasi 
cacing tanah dengan C-organik dan N-total sehingga didapat kesimpulan yang akan mewakili hasil penelitian mengenai korelasi hubungannya.

\section{HASIL DAN PEMBAHASAN}

Hasil penelitian menunjukan populasi, biomassa cacing tanah pada pengambilan sampel pertama di Dusun 1 pada lahan budidaya hortikultura tidak ditemukan populasi cacing tanah pada setiap kedalaman. Sedangkan pada pengambilan sampel ke dua di dusu tiga pada lahan monokultur kopi di temukan cacing tanah pada semua kedalaman, namun populasinya berbeda (Tabel 1).

Tabel 1. Hasil Analisis Populasi, Biomassa dan Rasio Biomassa dan Populasi Cacing Tanah Pada Lahan Hortikultura dan Monokultur Tanaman Kopi.

\begin{tabular}{|c|c|c|c|c|c|}
\hline \multirow{2}{*}{ No } & \multirow{2}{*}{ SPL } & \multirow{2}{*}{ Kedalaman } & \multicolumn{3}{|c|}{ Cacing Tanah } \\
\hline & & & $\mathrm{P}\left(\right.$ luas $\left.\mathrm{m}^{2}\right)$ & $\mathrm{B}($ gram $)$ & $\mathrm{B}: \mathrm{P}$ \\
\hline \multirow{3}{*}{1 . } & \multirow{3}{*}{ Hortikultura } & $0-10$ & - & - & - \\
\hline & & $10-20$ & - & - & - \\
\hline & & $20-30$ & - & - & - \\
\hline \multirow{3}{*}{2.} & \multirow{3}{*}{ Kopi Monokultur } & $0-10$ & 41 & 9 & 0,21 \\
\hline & & $10-20$ & 10 & 1 & 0,06 \\
\hline & & $20-30$ & 1 & 0,1 & 0,01 \\
\hline
\end{tabular}

Keterangan: $\mathrm{SPL}=$ Sistem Penggunaan Lahan, $\mathrm{P}=$ Populasi, $\mathrm{B}=$ Biomassa, $\mathrm{B}: \mathrm{P}=$ Biomassa : Populasi.

Tabel 1 memperlihatkan bahwa populasi dan biomassa cacing tanah pada pengambilan sampel pertama di Dusun 1 pada lahan hortikultura Desa Nduaria Kecamatan Kelimutu, tidak di temukan cacing tanah pada semua ke dalaman. Hal ini di sebabkan karena tidak ada bahan atau makanan serasah bagi cacing tanah akibat intensitas penggunaan lahan dan penggunaan bahan kimia yang berlebihan yang berdampak terhadap populasi cacing tanah. Masukan serasah sangat mempengaruhi keberadaan cacing tanah karena sersah di anggap sebagai sumber makanan yanag paling baik bagi cacing tanah karena karbohidratnya relatif tinggi dan rendahnya kandungan ligno selulosenya. Cacing tanah tidak mampu makan serasah segar yang baru jatuh dari pohon. Serasah tersebut membutuhkan periode tertentu untuk lapuk 
Muksin : Hubungan populasi cacing tanah terhadap C-organik dan N-total

atau terurai sampai cacing tanah mampu memakannya (Dewi, 2006).

Keberadaan cacing tanah pada lahan yang tidak terganggu akan menjaga proses siklus hara berlangsung secara terus menerus. Lahan terganggu (lahan pertanian) pada umumnya memiliki cacing tanah yang mengalami penurunan populasi yang disebabkan oleh penurunan atau hilangnya sejumlah spesies tumbuhan, penurunan produksi serasah, perubahan sifat biologis, fisik dan kimia tanah, penurunan populasi fauna lain dan mikroorganisme tanah, dan perubahan iklim mikro ke arah yang kurang menguntungkan bagi pertumbuhan makhluk hidup di dalamnya (Nuril, 1999).

Dari hasil wawancara dengan para petani desa Nduaria di Dusun 1, intensitas penggunaan lahan budidaya tanaman hortikultura sangat tinggi sehingga populasi cacing tanah tidak ada. Penggunaan lahan yang berlebihan merupakan salah satu faktor yang mempengaruhi kesuburan lahan seperti menurunkan kualitas sumber daya lahan sehingga diarahkan pada perbaikan struktur fisik, komposisi kimia dan aktivitas biota tanah yang optimum bagi tanaman. Perbedaan sistem pengelolaan lahan (tanah dan tanamannya) akan berpengaruh terhadap kondisi ekosistem pada umumnya. Oleh karena itu, lahan dapat dikatakan sebagai ekosistem karena adanya hubungan yang dinamis antara organisme yang ada di atas lahan tersebut dengan perubahan lingkungannya. Lebih lanjut lingkungan yang terganggu atau terdegradasi pada umumnya memiliki fauna tanah yang mengalami penurunan komposisi maupun populasi yang disebabkan oleh penurunan atau hilangnya sejumlah spesies tumbuhan, penurunan kekayaan deposit seresah, perubahan sifat biologis, sifat fisik kimia tanah dan perubahan iklim mikro (Nuril et al., 1999; Erniwati, 2008).

Seringnya penggunaan bahan kimia oleh para petani Desa Nduaria seperti pupuk kimia dan pestisida kimia berdampak pada populasi cacing tanah. Cacing tanah sensitif dan rentan terhadap bahan kimia tanah terutama agrokimia karena mereka kekurangan kutikula keras di sekitar tubuh mereka (Nahmani et al., 2007).

\section{Populasi Cacing Tanah Pada Lahan Monokultur Tanaman Kopi}

Berdasarkan hasil pengamatan (Tabel 1.), populasi cacing tanah pada pengambilan sampel kedua di Dusun 3 pada lahan kopi monokultur Desa Nduaria Kecamatan Kelimutu, ditemukan pada setiap kedalaman. Penyebaran populasi pada kedalaman 0-10 memiliki jumlah populasi cacing tanah yang tertinggi sebanyak 41 ekor $\mathrm{m}^{2}$, pada 
kedalaman 10-20 di temukan cacing tanah sebanyak 10 ekor $\mathrm{m}^{2}$ dan kedalaman 20-30 di temukan 1 ekor $\mathrm{m}^{2}$. Dari data sebaran populasi di setiap kedalaman dapat di lihat bahwa populasi cacing tanah yang tertinggi berada pada ke dalaman 0-10. Hal ini diduga karena perilaku dan kebiasaan kelompok cacing tanah pada lahan tersebut merupakan cacing tanah pemakan seresah tanaman yang ada di permukaan tanah.

\section{Biomassa Cacing Tanah}

Berdasarkan hasil pengamatan (Tabel 1.), biomassa cacing tanah pada pengambilan sampel kedua di Dusun 3 pada lahan monokultur tanaman kopi desa Nduaria Kecamatan Kelimutu. Biomassa cacing tanah pada kedalaman yang berbeda memiliki berat yang tidak seimbang antara kedalaman yang satu dengan kedalaman yang lainnya. Hal ini di sebabkan karena keberadaan bahan makanan bagi cacing tanah pada kedalaman tersebut tidak stabil. Kedalaman yang mempunyai jumlah biomasa cacing tanah yang paling tinnggi adalah pada ke dalaman 0-10 cm, dan diikuti kedalaman 10-20 cm dan 20-30 cm. Biomassa cacing tanah yang paling tinggi berada pada kedalaman 0-10 $\mathrm{cm}$ disebabkan karena jumlah bahan makanan bagi cacing tanah ini lebih banyak berada pada permukaan tanah.

\section{Rasio Biomassa dan Populasi Cacing Tanah}

Kedalaman 0-10 cm, 10-20 cm dan 20$30 \mathrm{~cm}$ memiliki kepadatan populasi dan biomasa cacing tanah yang tidak seimbang. Perbandingan antara kedalaman 0-10, 10-20 dan 20-30 mempunyai perbedaan yang tidak seimbang dikarenakan kondisi tanah atau faktor fisik tanah yang tidak mendukung untuk cacing tanah dapat dijadikan habitatnya.

Cacing tanah merupakan biota tanah yang banyak dijumpai pada lahan dan mempunyai peranan yang menguntungkan dalam ekosistem tanah. Cacing tanah berperan dalam dekomposisi dan menetralisir bahan organik. Proses dekomposisi materi organik menyebabkan perubahan struktur tanah sehingga dapat meningkatkan perubahan aerase tanah serta kemampuan tanah menahan air. Kepadatan populasi cacing tanah dan biomasa cacing tanah sangat bergantung pada faktor fisik-kimia tanah dan tersedianya makanan yang cukup bagi cacing tanah. Pada tanah yang berbeda faktor fisik kimia tanahnya tentu kepadatan cacing tanahnya juga berbeda. Demikian juga jenis tumbuh tumbuhan yang tumbuh pada suatu daerah sangat menentukan jenis cacing tanah dan kepadatan populasinya di daerah tersebut. Selain itu serasah pada 
Muksin : Hubungan populasi cacing tanah terhadap C-organik dan N-total

lahan monokultur tanaman kopi Pada kedalaman tanah dan perbedaan mempengaruhi keberadaan cacing tanah. lahan yang berbeda, beberapa aspek Sistem budidaya seperti pola tanam kesuburan tanah juga berbeda. Hal ini mempengaruhi populasi cacing tanah.
C-Organik dan N-Total pada lahan
Hortikultura dan Monokultur Kopi Organik, dan N-Total yang cenderung naik ataupun turun. Hal tersebut disajikan pada Tabel 2 berikut:

terlihat pada kadar masing-masing $\mathrm{C}$ -

Tabel. 2. Kandungan C-Organik dan N-Total di lahan hortikultura dan monokultur kopi

\begin{tabular}{cccccc}
\hline \multirow{2}{*}{ No } & Kedalaman & \multicolumn{2}{c}{ Hortikultura } & \multicolumn{2}{c}{ Monokutur Kopi } \\
\cline { 3 - 6 } & & C-Organik (\%) & N-Total (\%) & C-Organik (\%) & N-Total (\%) \\
\hline 1 & $0-10$ & $3,03 \mathrm{~T}$ & $0,47 \mathrm{~S}$ & $8,24 \mathrm{ST}$ & $1,57 \mathrm{ST}$ \\
2 & $10-20$ & $3,00 \mathrm{~S}$ & $0,46 \mathrm{~S}$ & $7,15 \mathrm{ST}$ & $1,37 \mathrm{ST}$ \\
3 & $20-30$ & $3,01 \mathrm{~T}$ & $0,46 \mathrm{~S}$ & $7,69 \mathrm{ST}$ & $1,47 \mathrm{ST}$ \\
\hline
\end{tabular}

Keterangan: $\mathrm{S}=$ sedang, $\mathrm{T}=$ tinggi, $\mathrm{ST}=$ sangat tinggi

\section{C-Organik dan N-Total Pada Lahaan} Hortikultura

Dari hasil analisis C-organik tanah pada lahan hortikultura Desa Nduaria di Dusun 1 Kecamatan Kelimutu, memiliki nilai C-organik yang berbeda pada penambahan kedalaman, pada ke dalaman 010 nilai C-organik 3,03\%, pada ke dalaman 10-20 mengalami nenurunan nilai C-organik menjadi 3,00\% dan pada ke dalaman 20-30 terjadi peningkatan nilai $\mathrm{C}$-organik menjadi $3,01 \%$.

Secara umum kriteria penilaian Corganik pada lahan hortikulura bervariasi Tinggi dan Sedang, pada kedalaman 0-10 dan 20-30 memiliki kriteria penilaian tinggi, sedangkan pada ke dalaman 10-20 memiliki kriteria sedang, menurunya kriteria penilaian pada kedalaman 10-20 dari tinggi ke sedang kemungkinan telah terjadi sedikit degradasi lahan disebabkan oleh air hujan sehingga bahan organik menumpuk pada lapaisan bawahnya. Ichriani et al. (2013) menyatakan bahwa keberadaan bahan organik pada lapisan bawah diakibatkan karena adanya pengolahan tanah, pengangkutan oleh organisme tanah dan pencucian bahan organik.

Dari hasil analisis N-total pada lahan hortikultura Desa Nduaria di Dusun 1 Kecamatan Kelimutu, niliai N-total tidak berbeda jauh di semua ke dalaman. Pada 
kedalaman 0-10 nilai N-total 0,47\%, pada kedalaman 10-20 dan 20-30 memiliki nilai $\mathrm{N}$-total yang sama $0,46 \%$.

Secara umum kriteria penilaian N-total pada lahan hortikultura memiliki kriteria sedang yang berarti tanah tersebut termasuk tanah yang baik dan dapat digunakan untuk bercocok tanam karena nitrogen berfungsi untuk merangsang pertumbuhan tanaman secara keseluruhan seperti batang, cabang dan daun.

\section{C-Organik dan N-Total Pada Lahan} Monokultur Tanaman Kopi

Dari hasil analisis C-organik dalam setiap kedalaman pada lahan kopi monokultur Desa Nduaria di Dusun 3 Kecamatan Kelimutu, memiliki kandungan C-organik yang berbeda dengan kedalaman yang lainnya namun memiliki kriteria sangat tinggi di semua kedalaman, karena kadar Corganik pada lahan kopi monokultur di semua kedalaman lebih dari $>5,00 \%$. Dapat di lihat pada Table 2 bahwa pada kedalamaan 0-10 Cm C-organiknya 8.24\%, pada ke dalaman 10-20 Cm kadar Corganiknya menurun menjadi $7,15 \%$ dan pada ke dalaman 20-30 cm terjadi peningkatan kadar C-organik menjadi 7,69.

Tinggihnya kadar C-organik di lahan kopi monokultur di karenakan umur tanaman kopi sudah mencapai lebih dari tujuh tahun telah memberikan sumbangan bahan organik banyak, memiliki tajuk yang lebih lebar dan rapat, sehingga dapat melindungi permukaan tanah dari pukulan air hujan.

Dari hasil analisis N-total pada lahan Kopi Monokultur Desa Nduaria di Dusun 3 Kecamtan Kelimutu, memiliki niliai N-total yang berbeda di semua kedalaman. Pada kedalaman 0-10 nilai $\mathrm{N}$-total 1,57\%, pada kedalaman 10-20 mengalami penurunan menjadi, $\quad 1,37 \%$ dan 20-30 terjadi peningkatan nilai $\mathrm{N}$-total menjadi $1,47 \%$.

Secara umum kriteria penilaian $\mathrm{N}$-total pada lahan monokultur kopi memiliki kriteria sangat tinggi pada semua kedalaman. Hal ini disebabkan oleh hasil dekomposisi bahan organik pada lahan kopi monokultur lebih tinggi. Hal ini sesuai dengan literatur Damanik et al. (2010) yang menyatakan bahwa sumber utama nitrogen dalam tanah adalah dari hasil dekomposisi bahan organik. Selanjutnya dalam dekomposisi protein akan dilapuki oleh jasad renik menjadi asam amino kemudian menjadi ammonia $\left(\mathrm{NH}_{4}\right)$ dan Nitrat $\left(\mathrm{NO}_{3}\right)$ yang larut dalam tanah.

Keeratan Hubungan Antara Populasi, Biomassa, Biomassa : Populasi, C-organik dan N-total

Keeratan hubungan populasi terhadap C-organik dan N-total di sajikan pada Gambar 1 di bawah ini. 
Muksin : Hubungan populasi cacing tanah terhadap C-organik dan N-total


Gambar 1 Hubungan Biomassa Terhadap C-organik dan N-total

Hasil uji keeratan hubungan pada keeratan hubungan antara populasi cacing grafik di atas menujukan bahwa tingkat keeratan hubungan antara populasi cacing tanah dengan $\mathrm{C}$-organik yakni dengan nilai $\mathrm{R}^{2}=0,550$ (sedang). Populasi cacing tanah dengan C-organik menunjukan korelasi positif artinya berbanding lurus, semakin tinggi C-organik maka populasi cacing tanah semakin tinggi. Menurut Jhayauthi (2013), faktor C-organik tanah sangat mempengaruhi kehadiran cacing tanah. Semakin tinggi kadar C-organik maka jumlah cacing tanah yang ditemukan juga akan semakin banyak.

Hasil uji keeratan hubungan pada grafik di atas menunjukan bahwa tingkat tanah dengan $\mathrm{N}$-total yakni dengan nilai $\mathrm{R}^{2}=4,93$ (sedang). Populasi cacing tanah dengan N-total menunjukan korelasi positif artinya berbanding lurus semakin tinggi Ntotal maka populasi cacing tanah semakin tinggi. Menurut Barciha (2009), fauna tanah berperan dalam mendistribusikan nitrogen kedalam profil tanah. Sekresi dari fauna tanah kaya akan kandungan nitrogen.

\section{Keeratan Hubungan Biomassa Terhadap C-organik dan N-total}

Keeratan hubungan biomassa terhadap C-organik dan N-total disajikan pada Gambar 2 di bawah ini. 

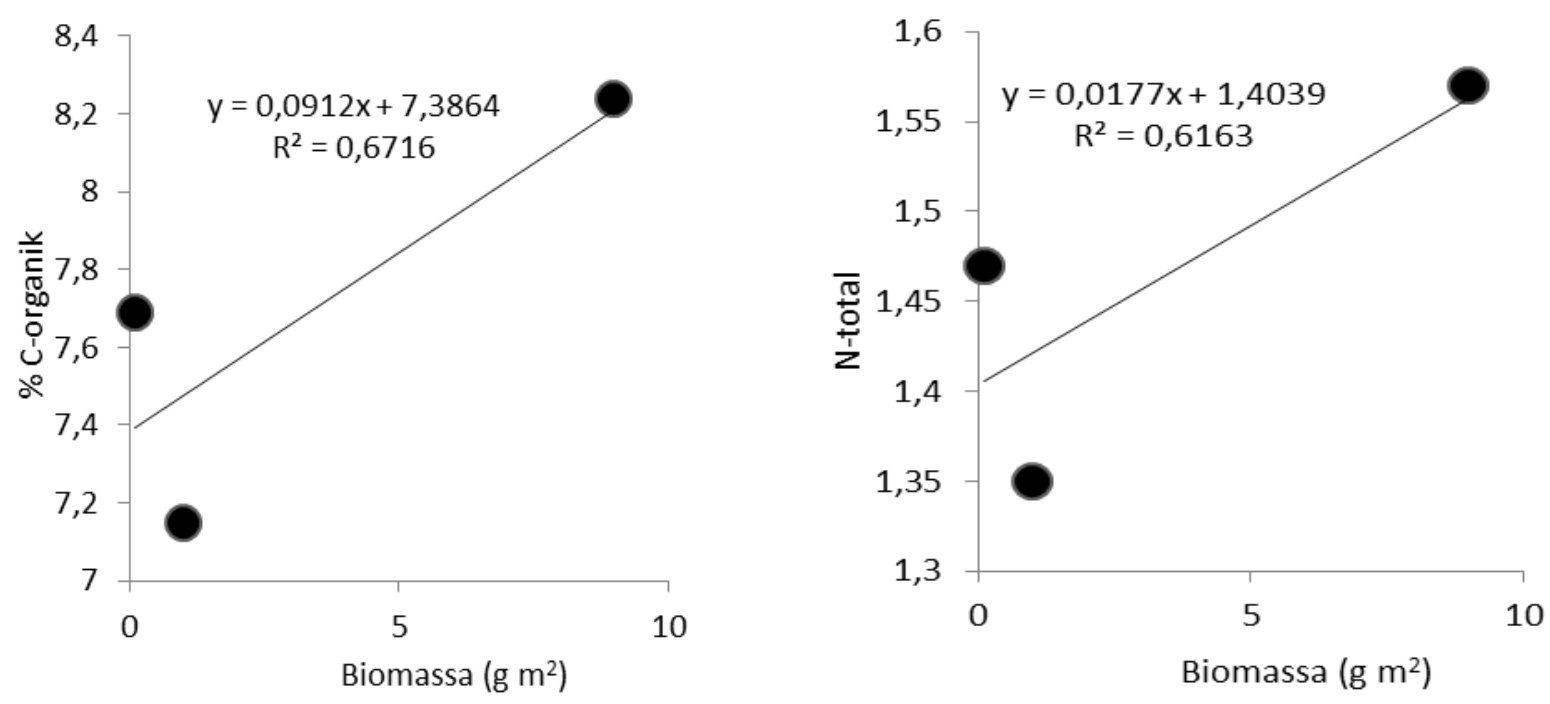

Gambar 2. Hubungan Biomassa Terhadap C-organik dan N-total

Hasil uji keeratan hubungan pada grafik di atas menujukan bahwa tingkat keeratan hubungan antara biomassa dengan C-organik yakni dengan nilai $\mathrm{R}^{2}=0,671$ (kuat). Biomassa dengan C-organik menunjukan korelasi positif artinya berbanding lurus, semakin tinggi C-organik maka biomassa semakin tinggi. Biomassa dapat menggambarkan jumlah C-organik yang berasal dari mikroorganisme yang hidup dalam tanah. Jumlah bahan organik mikroorganisme dalam tanah dan proporsinya terhadap C-organik yang semakin besar menunjukkan bahwa kemampuan tanah tersebut dalam mendukung kehidupan mikroorganisme semakin baik, sehingga proses transformasi unsur hara dapat terus berlangsung (Islam dan Weil, 2000).

Hasil uji keeratan hubungan pada kurva di atas menujukan bahwa tingkat keeratan hubungan antara biomassa dengan N-total yakni dengan nilai $\mathrm{R}^{2}=0,616$ (kuat). Biomassa dengan N-total menunjukan korelasi positif artinya berbanding lurus, semakin tinggi $\mathrm{N}$-total maka biomassa semakin tinggi. Tingginya unsur $\mathrm{N}$ dalam tanah akan menyebabkan jumlah biomassa mikroorganisme tanah akan meningkat sehingga dapat membentuk jaringan tubuh dan memacu pertumbuhan mikroorganisme untuk melakukan proses dekomposisi bahan organik (Bangun, 2002). 
Muksin : Hubungan populasi cacing tanah terhadap C-organik dan N-total

\section{Keeratan Hubungan Biomassa : Populasi Terhadap C-organik Dan N-total}

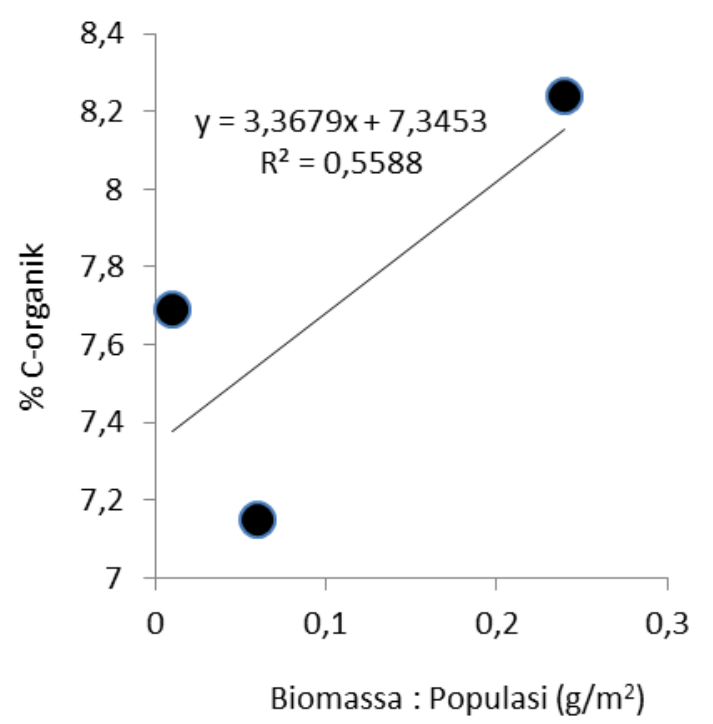

Keeratan hubungan biomassa terhadap C-organik dan N-total disajikan pada Gambar 3 di bawah ini.

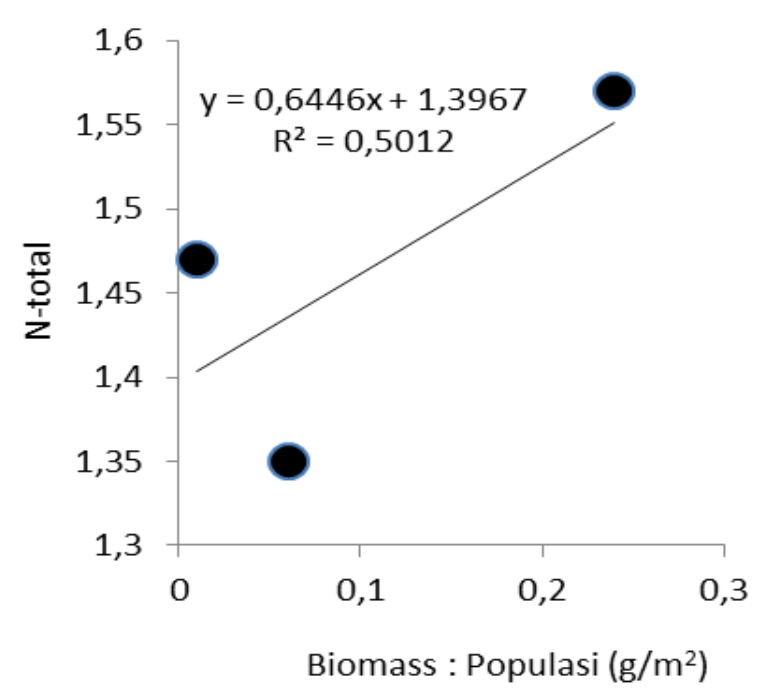

Gambar 3 Hubungan Biomassa : Populasi Terhadap C-organik dan N-total

Hasil uji keeratan hubungan pada grafik di atas menujukan bahwa tingkat keeratan hubungan antara biomassa ; populasi dengan C-organik yakni dengan nilai $\mathrm{R}^{2}=0,558$ (sedang). biomassa : populasi dengan C-organik menunjukan korelasi positif artinya berbanding lurus, semakin tinggi C-organik maka biomassa: populasi semakin tinggi.

Hasil uji keeratan hubungan pada grafik di atas menujukan bahwa tingkat keeratan hubungan antara biomassa : populasi dengan $\mathrm{N}$-total yakni dengan nilai $\mathrm{R}^{2}=0,501 \quad$ (sedang). biomassa : populasi dengan N-total menunjukan korelasi positif artinya berbanding lurus, semakin tinggi $\mathrm{N}-$ total maka Biomassa: Populasi semakin tinggi. Menurut Russel (1950), populasi cacing tanah juga dipengaruhi oleh kadar nitrogen tanah dan karbon tanah.

\section{SIMPULAN}

Berdasarkan penelitian yang dilakukan mengenai hubungan populasi cacing tanah terhadap N-total dan C-organik di lahan budidaya hortikultura dan monoklutur kopi di Desa Nduaria Kecamatan Kelimutu dapat disimpulkan bahwa tidak ditemukan cacing tanah pada lahan hortikultura di semua kedalaman, sedangkan pada lahan kopi 
monokultur ditemukan cacing tanah di semua kedalaman. Populasi cacing tanah tertinggi pada lahan kopi monokultur berada di kedalaman 0-10 populasinya sebanyak 41 ekor $\mathrm{m}^{2}$. Biomassa tertinggi berada pada kedalaman 0-10 yaitu 9 (g) dan biomassa : populasi tertinggi berada pada kedalaman 010 yaitu 0,21. Hasil uji keeratan hubungn antara populasi cacing tanah, biomassa dan biomasa : populasi terhadap C-organik dan $\mathrm{N}$-total menunjukan korelasi positif artinya berbanding lurus semakin tinggi $\mathrm{C}$-organik dan N-total maka populasi, biomassa dan biomassa : populasi juga semakin tinggi.

\section{UCAPAN TERIMAKASIH}

Ucapan terima kasih penulis sampaikan kepada pihak yang berkontribusi dalam mendukung dalam penelitian ini yaitu, petani pemilik lahan yang telah mempersilahkan peneliti melakukan penelitian, dosen pembimbing yang telah membimbing dalam penulisan artikel ini.

\section{DAFTAR PUSTAKA}

Anwar, E.K. 2007. Pengaruh Inokulan Cacing Tanah dan Pemberian Bahan Organik Terhadap Kesuburan dan Produktivitas Tanah. Jurnal Tanah Tropika, 12 (2) : 121-130.
Bangun, I. 2002. Pengembangan Metode Penetapan Biomassa Karbon Mikroorganisme Tanah (C-mik) dengan Menggunakan Ultrasonik Processor. Skripsi. Institut Pertanian Bogor

Barciha, M.F,2009. Agroekosistem Tanah Mineral Masam . Yogyakarta. Gadjah Mada University Press

Batubara, M. H., Niswati, A., Yusnaini, S., \& Arif, M. A. S. (2013). Terhadap Populasi Dan Biomassa Cacing Tanah Pada Pertanaman Tebu ( Saccharum Officinarum $L$.) TAHUN KE 2. 1(1), 107-112.

Dewi, W. S. 2007. Dampak Alih Guna Hutan Menjadi Lahan Pertanian: Perubahan Diversitas Cacing Tanah dan Fungsinya Dalam Mempertahankan Pori Makro Tanah. Disertasi. Program Pasca Sarjana Fakultas Pertanian Universitas Brawijaya. Malang. 145 hlm.

Fonte, S. J., \& Six, J. (2010). Earthworms and litter management contributions to ecosystem services in a tropical agroforestry system. 20(4), 10611073. 
Muksin : Hubungan populasi cacing tanah terhadap C-organik dan N-total

Hani, A., \& Suhaendah, E. (2019). Diversity

Of Soil Macro Fauna And Its Role

On Soil Diversity Of Soil Macro

Fauna And Its Role On Soil Fertility

In Manglid. 6(1), 61-68. https://doi.org/10.20886/ijfr.2019.6.

$1.61-68$

Handayanto, E dan K. Hairiah. 2007. Biologi

Tanah. Pustaka Adipura.

Yogyakarta. 62 hlm.

Irawati, J., Hidayah, W. N., Wulandari, A., \& Biodiversity, M. (2019). Keanekaragaman Makrofauna

Tanah Diurnal pada Ketinggian 1200 Mdpl di Gunung Buthak. 291294.

Islam, K.R. and R.R. Weil. 2000. Soil quality indicator properties in midAtlantic soils as influenced by conservation management. J. Soil and Water Cons. 55:69-78.

Jhayanti, S. 2013. Komposisi Komunotas Cacing Tanah Pada Lahan Pertanian Organic Dan Anorganik ( Studi Kasus Kajian Cacing Tanah Untuk Meningkatkan Kesubutan Tanah Di Desa Raya Kecamatan Berastagi Kabupaten Karo). Tesis. Universitas Sumatara Uatara Fakultas
Matematika Dan Ilmu Pengetahuan Alam Program Pascasarjana.

Luthfiyah, H. (2014). Keanekaragaman dan Kepadatan Cacing Tanah di Perkebunan teh PTPN XII Bantaran Blitar 2014 Keanekaragaman dan Kepadatan Cacing Tanah di Perkebunan teh PTPN XII Bantaran Blitar Hidayatul Luthfiyah (10620050). (10620050), 1-9.

Muys, B. and P.H. Granval. 1997. Earthworms as Bio-indicators of Forest Site Quality. Journal of Soil Biology and Biochemistry, 29(1): 323-328

Nuril, H., B. P. Naiola, E. Sambas, F. Syarif, M. Sudiana, J. S. Rahajoe, Suciatmih, T. Juhaeti, dan Y. Suhardjono. 1999. Perubahan Bioekofisik Lahan Bekas Penambangan Emas di Jampang dan Metoda Pendekatannya untuk upaya reklamasi. Laporan Teknik Proyek Penelitian Pengembangan dan Pendayagunaan Potensi Wilayah, Tahun 1998/1999. Puslitbang Biologi LIPI. 25 hlm.

Russle, E.J. (1950). Soil condition and plant growth. Longman. London. 
Sagita, L., Siswanto, B., \& Hairiah, K. (2014). Berbagai Sistem Penggunaan Lahan Di Sub Das Konto. Jurnal Tanah Dan Sumberdaya Lahan, I(1), 53-63.

Schwab, N., Schickhoff, U., \& Fischer, E. (2015). Agriculture , Ecosystems and Environment Transition to agroforestry signi fi cantly improves soil quality: A case study in the central mid-hills of Nepal. "Agriculture, Ecosystems and Environment," 205, 57-69. https://doi.org/10.1016/j.agee.2015. 03.004

Yasin, S. 2004. Degradasi Lahan Akibat Berbagai Jenis Penggunaan Lahan di Kabupaten Dharmasraya. Jurnal Solum Vol. I No 2 Juli 2004 : 69-73 